\title{
Superantigen Properties of a Human Sialoprotein Involved in Gut-associated Immunity
}

\author{
G. J. Silverman, ${ }^{\star}$ P. Roben, ${ }^{\star}$ J.-P. Bouvet, ${ }^{\ddagger}$ and M. Sasano* \\ *The Sam and Rose Stein Institute for Research on Aging and the Theodore Gildred Cancer Center, Department of Medicine, University
} of California, San Diego, La Jolla, California 92093; and ${ }^{\ddagger}$ the Unité d'Immunologie Microbienne, Institut Pasteur, Paris, France

\begin{abstract}
Protein Fv (pFv) is a recently described 175-kD gut-associated sialoprotein with a potent capacity for augmentation of antibody-dependent immune functions. To investigate the molecular basis for Fab-mediated binding of pFv, we evaluated a panel of 52 monoclonal IgM and found that $\sim 40 \%$ bound pFv. Whereas the majority $(\geq 75 \%)$ of $V_{H} 3$ and $V_{H} 6$ IgM strongly bound pFv, only a small minority $(<20 \%)$ of IgM from other $V_{H}$ families bound $p F v$, and these antibodies had weaker binding interactions. Inhibition studies suggested that all binding occurred at the same (or overlapping) site(s) on pFv. Surface plasmon resonance studies demonstrated binding affinity constants up to $6.7 \times 10^{8} \mathrm{M}^{-1}$ for pFv. Biopanning of IgM and IgG Fab phage-display libraries with pFv preferentially selected for $V_{H} 3$ and $v_{H} 6$ antibodies, but also obtained certain $V_{H} 4$ IgM. $V_{H}$ sequence analyses of $36 \mathrm{pFv}$-binding antibodies revealed that binding did not correlate with $C D R$ sequence, $J_{H}$, or $L$ chain usage. However, there was preferential selection of $\mathrm{pFv}$ binders with $V_{H} C D R 3$ of small size. These studies demonstrate that a protein which enhances immune defense in the gut has structural and functional properties similar to known superantigens. (J. Clin. Invest. 1995. 96:417-426.) Key words: repertoire • antibody $\bullet B$ cell $\bullet$ variable region $\bullet$ immunity
\end{abstract}

\section{Introduction}

Protein $\mathrm{Fv}(\mathrm{pFv})^{1}$ is a $175-\mathrm{kD}$ dimeric sialoprotein, produced in the human liver, which has unique properties that may aid in immune defense in the gut. In vitro studies have demonstrated that binding of $\mathrm{pFv}$ by antibodies enhances complement activation (1), and by interacting with the Fab domain of the surface membrane-associated IgE, $\mathrm{pFv}$ can also aid in the release of histamine and sulfidopeptide leukotriene $\mathrm{C} 4$ by human basophils and mast cells (2). In addition, in vitro studies indicate that the addition of $\mathrm{pFv}$ augments agglutination of pathogens

Address correspondence to Gregg J. Silverman, Department of Medicine-0663, University of California, San Diego, 9500 Gillman Drive, La Jolla, CA 92093-0663. Phone: (619) 534-5439; FAX: (619) 5345399.

Received for publication 16 December 1994 and accepted in revised form 6 March 1995.

1. Abbreviations used in this paper: BBS, borate-buffered saline; FR, framework region; $\mathrm{H}$ and $\mathrm{L}$, heavy and light chains; $K_{\mathrm{a}}$, association constant; pFv, protein Fv; SpA, staphylococcal protein A.

J. Clin. Invest.

(c) The American Society for Clinical Investigation, Inc. 0021-9738/95/07/0417/10 \$2.00

Volume 96, July $1995,417-426$ by antivirus and by anti-Salmonella typhi antibodies, which may improve conveyance in the mucus stream and excretion of pathogens from the gut (3).

$\mathrm{pFv}$ derives these diverse functional properties from its unique Fab binding activity. A single molecule of $\mathrm{pFv}$ can bind six $\mathrm{F}\left(\mathrm{ab}^{\prime}\right)_{2}$ fragments (2). The $\mathrm{pFv}$ binding capacities of different antibodies vary greatly, but $\operatorname{IgM}, \operatorname{IgA}, \operatorname{IgG}$, and $\operatorname{IgE}$ can display $\mathrm{pFv}$ binding activity $(4,5) . \mathrm{pFv}$ binding capacity has also been detected in the Ig from a variety of mammalian, avian, reptilian, amphibian, and fish species (4). Studies using isolated Ig fragments have clearly demonstrated that binding to $\mathrm{pFv}$ is mediated by the $\mathrm{V}_{\mathrm{H}}$ region (5). As this interaction does not block binding of either IgG or IgM antibodies to their conventional ligands, pFv presumably interacts with Fab outside of the conventional antigen-binding pocket $(3,5)$.

To investigate the molecular basis for antibody binding of $\mathrm{pFv}$, we applied approaches and insights originally developed for studies of Fab-mediated binding of staphylococcal protein $A(\mathrm{SpA})(6-10)$. We sought to evaluate the spectrum of $\mathrm{V}_{\mathrm{H}}$ regions used in $\mathrm{pFv}$ binding and determine whether binding of $\mathrm{pFv}$ could preferentially select for antibodies encoded by certain $\mathrm{V}_{\mathrm{H}}$ gene segments. The $\mathrm{pFv}$ binding capacity of a panel of human monoclonal IgM was first evaluated, and we investigated binding within large antibody repertoires of a healthy adult obtained from combinatorial Fab phage-display libraries. These studies revealed that the affinity of pFv binding is comparable to that of a conventional antigen binding interaction, but the frequency of binders and the structural correlates for the interaction are akin to those of a superantigen.

\section{Methods}

Immunoblot analysis of IgM binding to $p F v$. The isolation of $\mathrm{pFv}$ has previously been described (11), and the activity and purity of the pFv preparations from donors TER and FAR have been extensively documented $(2-5,11)$. To identify the IgM proteins that bind $\mathrm{pFv}, 10 \times$ concentrated $\mathrm{pFv}$ samples or control proteins were dissolved in reducing ( $8 \mathrm{M}$ urea and 2-mercaptoethanol) buffer and electrophoretically separated on $10 \%$ polyacrylamide gels, as previously described $(10,12)$. Replicate gels were electrotransferred to Immobilon P membrane (Millipore Corp., Bedford, MA), air dried, rewetted, and blocked with 1\% nonfat dried milk, $0.1 \%$ gelatin in borate-buffered saline, $\mathrm{pH} 8.2$ (BBS) for $1 \mathrm{~h}$. Immunoblots were incubated with IgM preparations at $1 \mu \mathrm{g} /$ $\mathrm{ml}$ in blocking solution for $1 \mathrm{~h}$ at room temperature with rocking, followed by extensive washing with $0.05 \%$ Tween $20-$ BBS and incubation with horseradish peroxidase-conjugated goat anti-human IgM (Novabiochem, La Jolla, CA) diluted in rabbit IgG at $10 \mu \mathrm{g} / \mathrm{ml}$ for 1 $h$ at room temperature with rocking. Blots were washed and developed with a chemiluminescent detection reagent (Amersham Corp., Arlington Heights, $\mathrm{IL}$ ), followed by exposure of autoradiograms.

ELISA studies. The current $\mathrm{pFv}$ binding assay was used because it enables the discrimination of strong from weak $\mathrm{pFv}$ binders and can be used for biopanning of phage-display antibody libraries. To evaluate for pFv binding, microtiter wells (Costar Corp., Cambridge, MA) were precoated with polylysine at $50 \mu \mathrm{g} / \mathrm{ml}$ in water, sealed, and incubated 
overnight at $4^{\circ} \mathrm{C}$. Plates were emptied and rinsed once with distilled water and then incubated with pFv from donor TER $(2-5,11)$, or a control antigen, orosomucoid (Novabiochem) at $1 \mu \mathrm{g} / \mathrm{ml}$ in water with $0.25 \%$ glutaraldehyde for $1 \mathrm{~h}$ at $37^{\circ} \mathrm{C}$. Wells were emptied and blocked by completely filling with $100 \mathrm{mM}$ glycine, $0.1 \%$ BSA in PBS, pH 7.2, for $30 \mathrm{~min}$ at room temperature. Plates were further blocked with $3 \%$ BSA in $0.1 \mathrm{M} \mathrm{NaHCO}, \mathrm{pH} 8.6$, for $30 \mathrm{~min}$ at $37^{\circ} \mathrm{C}$. Other control antigens, transferrin, actin, BSA, or tetanus toxoid was precoated on wells at $5 \mu \mathrm{g} / \mathrm{ml}$ in PBS overnight at $4^{\circ} \mathrm{C}$ and then blocked with $1 \%$ BSA in PBS for $1 \mathrm{~h}$ at room temperature. IgM proteins, Fab, or a polyclonal IgM standard at $1 \mu \mathrm{g} / \mathrm{ml}$ in $1 \%$ BSA in $0.1 \mathrm{M} \mathrm{NaHCO}_{3}, \mathrm{pH}$ 8.6, was then added in replicate, and the plates were sealed and incubated for $90 \mathrm{~min}$ at $37^{\circ} \mathrm{C}$. Plates were washed five times with $0.05 \%$ Tween 20-BBS and incubated with horseradish peroxidase-labeled anti-human IgG Fab (Pierce, Rockford, IL) diluted 1:3,000 in PBS for $1 \mathrm{~h}$ at room temperature. Plates were washed five times and developed with substrate. The human monoclonal IgM include antibodies with rheumatoid factor, anti-I/i cold agglutinin, anti-pneumococcal polysaccharide type 3, anti-DNA, and anti-Sm specificity (sources reported in references $6,8,13$, and 14). Fab-producing bacterial clones were tested for pFv binding activity only if the plasmids contained the appropriately sized V gene inserts and produced detectable light (L) chains. Designation as an $\mathrm{pFv}$ binder required an absorbance greater than twice the mean of negative controls (or greater than five times SD above negative controls) and $>30 \%$ inhibition of $\mathrm{pFv}$ binding activity by soluble $\mathrm{pFv}$ in competition ELISA.

The evaluation of the antibody binding capacity of Fab from the phagemid libraries used previously described methods $(9,15-17)$. The bacterial supernatants were used directly or stored at $-20^{\circ} \mathrm{C}$. By comparison with human IgG Fab (Novabiochem) standards, the concentration of the Fab in each extract was measured as previously described except plates were precoated with affinity-purified goat anti-human IgG Fab (Sigma Chemical Co., St. Louis, MO) at $5 \mu \mathrm{g} / \mathrm{ml}$ in PBS, pH 7.2, overnight at $4^{\circ} \mathrm{C}$ and then blocked with $1 \% \mathrm{BSA}$ in PBS for $1 \mathrm{~h}$ at room temperature before addition of the samples in replicate.

To compare binding avidities and determine whether antibodies recognized a common site on $\mathrm{pFv}$, competition ELISA was performed using purified adult polyclonal IgM (Novabiochem) that was labeled with $N$-hydroxyl-succimide-biotin (Novabiochem). ELISA wells were precoated with pFv, as previously described, and replicate wells were incubated with either polyclonal IgM-biotin at $500 \mathrm{ng} / \mathrm{ml}$ alone or polyclonal IgM-biotin at $500 \mathrm{ng} / \mathrm{ml}$ with different concentrations of unlabeled antibodies or IgG Fc for $1 \mathrm{~h}$ at $37^{\circ} \mathrm{C}$. By comparison with a series of dilutions of polyclonal IgM-biotin in the absence of inhibitor, the relative inhibition was determined (e.g., values equivalent to that for polyclonal IgM-biotin at $250 \mathrm{ng} / \mathrm{ml}$ represented $50 \%$ inhibition).

Surface plasmon resonance determinations of $p F v$ binding affinity. Binding kinetics were measured using the surface plasmon resonance technique on the BIAcore instrument (Pharmacia LKB Biotechnology Inc., Piscataway, $\mathrm{NJ})(18,19)$. This enables real-time kinetics analysis of antibody-antigen interactions in a label-free mode. Immobilization of the pFv and the binding of all subsequent molecules were measured using a direct optical sensing technique based on total internal reflectance. Adapting the ELISA precoating procedure, activation solution (Pharmacia LKB Biotechnology Inc.) was used to immobilize $0.1 \%$ poly-L-lysine (Sigma Chemical Co.) on the 100-nm-thick layer of dextran coating the gold film of the biosensor chip (18), resulting in a signal increase of $3,400 \mathrm{RU}$. Next, a $10 \times$-concentrated $\mathrm{pFv}$ (donor TER) solution with $0.25 \%$ glutaraldehyde was added, resulting in a signal increase of $4,100 \mathrm{RU}$. The surface was then blocked by two

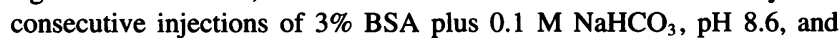
$1 \%$ BSA plus $0.1 \mathrm{M} \mathrm{NaHCO}_{3}, \mathrm{pH}$ 8.6. To assess binding, each antibody was added at final concentrations of $5-500 \mu \mathrm{g} / \mathrm{ml}$. PBS was allowed to flow over the surface after each injection for $10 \mathrm{~min}$ so that at least $30 \%$ of the bound antibody dissociated. The binding was displayed in real time as a sensogram, which was analyzed using kinetics software to give final affinity values (19).

Creation of combinatorial Ig libraries. Using previously described methods $(9,15-17)$, we recently constructed an IgG library (9), now designated JG. An IgM library, designated JM, was made from the same peripheral blood sample that was the source of the JG library, and this also used the same L chain phagemid library used for the JG library. To amplify the heavy $(\mathrm{H})$ chain genes, in separate reactions an antisense (downstream) primer (termed CM1) (5'-GCTCACACTAGTAGGCAGCTCAGCAATCAC- $\left.3^{\prime}\right)$ derived from the $\mu$ constant region was paired individually with sense (upstream) $V_{H}$ oligonucleotide primers from the previously described panel, with an additional $\mathrm{V}_{\mathrm{H}}$ primer, (5'CAGGTGCAGCTACTCGAGTGGGGC- $3^{\prime}$ ), designated $\mathrm{V}_{\mathrm{H}} 4 \mathrm{gs}$, which ensured representation of rearrangements of the $V_{H} 4-21$ gene segment. The $\mathrm{H}$ chain genes were cloned after the $\mathrm{L}$ chain genes to avoid destroying $\mathrm{V}_{\mathrm{H}}$ 4-21 rearrangements, which contain internal SacI sites. In these libraries, there were $>10^{7} \mathrm{CFU}$ for both $\mathrm{H}$ and $\mathrm{L}$ chain transformants. The PCR conditions used are associated with $<1$ mutation in 1,500 bases due to Taq polymerase infidelity. Each pComb3 clone was designated according to the library from which it was obtained (JM or JG). Clones from the original library include the " 0 " prefix, and selected clones include the prefixes pFv1-, pFv2-, and pFv3-, based on the round of selection.

Antibody selection. As previously described (9, 15-17), antigenspecific clones were selected using a modified panning procedure (20). For selection of pFv-specific clones, microtiter wells were precoated and blocked as previously described. For each round of selection, two of these wells were filled with $50 \mu$ l of phage library containing $10^{11}$ CFU in PBS and incubated for $2 \mathrm{~h}$ at $37^{\circ} \mathrm{C}$. After extensive washing, binding phage were eluted with glycine- $\mathrm{HCl}, \mathrm{pH} 2.5$, which was rapidly neutralized with $2 \mathrm{M}$ Tris-base. Phage were then amplified.

Colony hybridization to survey $V_{H}$ family diversity. To survey $V_{H}$ chain diversity within the pComb3 clones, an oligonucleotide-based hybridization method was adapted $(9,10,21)$ using 150-250 colonies per plate and Hybond-N discs (Amersham Corp.) Oligonucleotide hybridization studies used antisense sequences from diagnostic framework regions (designed by Dr. C. Rundle, University of Alabama, Birmingham, AL) that include the following: $\mu$ (H-13), 5'-CTCACAGGAGACGAGGGGGAAAAGGGTTGG-3'; V 1 (CR-8), 5'-AGCTCCATGTAGGCTGTGCTCGTGGACGTGTCCCTGGTCA-3'; $\mathrm{V}_{\mathrm{H}} 2$ (CR-2), 5'-GGTCCATGTTGGTCATTTTAAGGACCACCTGGTTT$3^{\prime} ; \mathrm{V}_{\mathrm{H}} 3$ (CR-3), 5'-GGCTCTCAGGCTGTTCATTTGCAGATACAGCGTGTTCTTG-3'; V 4 (CR-4), 5'-CGCGGCGGTCACAGAGCTCAGCTTCAGGGAGAACT-3'; $\mathrm{V}_{\mathrm{H}} 5$ (CR-5), 5'-ACTCCAGGCCTTTCCCGGGCATCTGGCGCA-3'; and $\mathrm{V}_{\mathrm{H}} 6$ (CR-6), 5'-AGCCACTCAAGGCCTCTCGATGGGGACTGCCTG-3'.

All hybridization studies were performed at least twice to ensure accuracy. On all blots, control $\mathrm{V}_{\mathrm{H}}$-containing plasmids were included to document specificity and signal intensity: 51P1 $\left(\mathrm{V}_{\mathrm{H}} 1\right), \mathrm{M} 60,\left(\mathrm{~V}_{\mathrm{H}} 2\right)$, 30P1 $\left(\mathrm{V}_{\mathrm{H}} 3\right), 58 \mathrm{P} 2\left(\mathrm{~V}_{\mathrm{H}} 4\right), 83 \mathrm{P} 2\left(\mathrm{~V}_{\mathrm{H}} 5\right), \mathrm{M} 71\left(\mathrm{~V}_{\mathrm{H}} 6\right)$, and 10P1 $\left(\mathrm{V}_{\mathrm{H}} 7\right)$.

DNA sequence determination. The nucleotide sequences encoding $\mathrm{V}_{\mathrm{H}}$ and $\mathrm{V}_{\mathrm{L}}$ regions were determined from double-stranded DNA using automated sequencing (Applied Biosystems, Inc., Foster City, CA). The oligonucleotide 5'-ATGGAGTCGGGAAGGAAGTC-3', termed SEQMB, from the $\mu$ constant region immediately adjacent to the $V_{H}$ region and other previously described oligonucleotides (9) were used to prime sequencing reactions. Sequences were analyzed with Macvector 4.0 (IBI, New Haven, CT) and Genetics Computer Group (Madison, WI) software packages and compared with comparison to the GenBank data base. To ensure accuracy, sequences were determined at least three times using two different primers.

\section{Results}

IgM that bind $p F v$. To evaluate the binding capacity of IgM for $\mathrm{pFv}$, immunoblots of $\mathrm{pFv}$ and control proteins were incubated with different IgM preparations. Species within polyclonal adult IgM identified the same bands at 85 and $175 \mathrm{kD}$ in $\mathrm{pFv}$ preparations from two different individuals (FAR and TER). The monoclonal $\mathrm{V}_{\mathrm{H}} 3 \mathrm{~V}_{\kappa} 3$ IgM (GLO), $\mathrm{V}_{\mathrm{H}} 1 \mathrm{~V}_{\kappa} 3$ IgM (KAS), and $\mathrm{V}_{\mathrm{H}} 6 \lambda$ IgM (L16) were also found to be reactive with the pFv by immunoblotting (data not shown). By compari- 

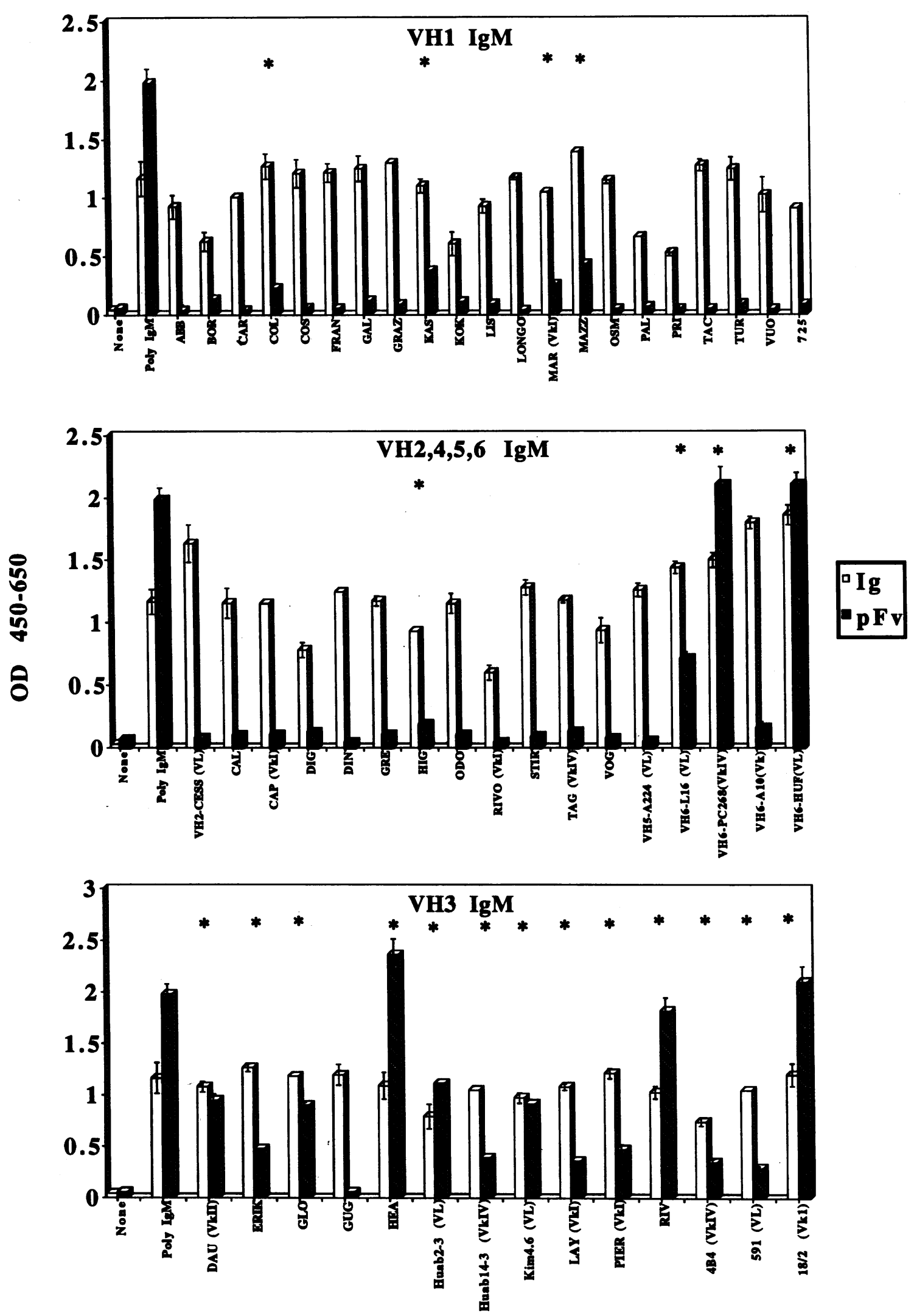

Figure 1. ELISA evaluation of human IgM for pFv binding activity. Direct binding evaluations were performed on a panel of 52 monoclonal human IgM. The proteins are organized according to $\mathrm{V}_{\mathrm{H}}$ family, and if known, $\mathrm{V}_{\mathrm{H}}$ region sequences of IgM with strong pFv binding activity are included in Fig. 3. Except where indicated, these IgM use $V_{\kappa} I I I L$ chains, and usage was presented in earlier publications $(6,8,13$, 14). For comparison, values for Ig content were also obtained. Values were determined in triplicate and are represented \pm SD. An asterisk indicates IgM with significant pFv binding capacity ( $>5$ SD above negative controls). 


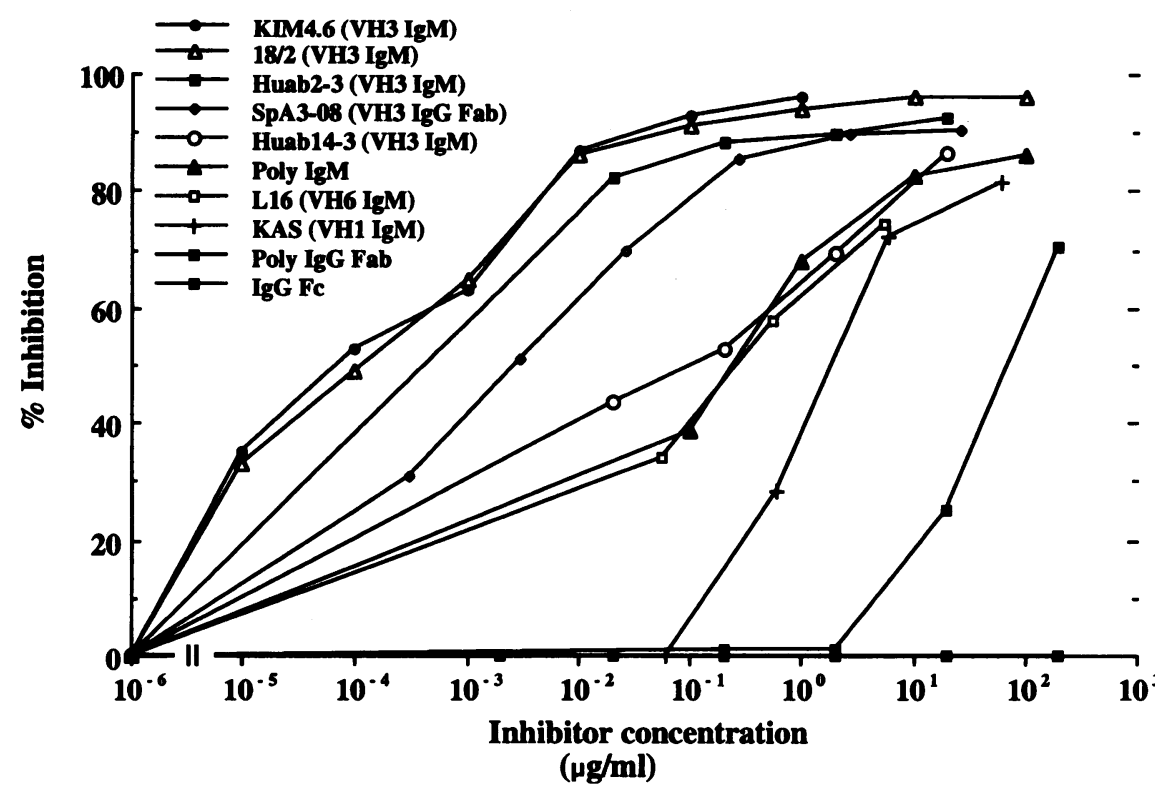

Figure 2. Competitive inhibition of polyclonal IgM binding of $\mathrm{pFv}$ by monoclonal IgM. Polyclonal IgM from the peripheral blood of healthy adults was biotinylated and added at a final concentration of $500 \mathrm{ng} / \mathrm{ml}$ to wells coated with $\mathrm{pFv}$. To evaluate the ability of different purified Ig to inhibit the binding of polyclonal IgM to $\mathrm{pFv}$, inhibitors were added at final concentrations between 0.01 and $200 \mu \mathrm{g} / \mathrm{ml}$ to aliquots of polyclonal IgM-biotin. All values were determined in duplicate. Without inhibitor, an OD $>1.5$ was obtained. Percent inhibition was determined by comparison with a standard curve of polyclonal IgM-biotin without inhibitor. son, $\mathrm{SpA}$, which has been shown to bind most $\mathrm{V}_{\mathrm{H}}$ 3-derived Ig $(6-9,22)$, was recognized only by the polyclonal IgM and the $\mathrm{V}_{\mathrm{H}} 3$ IgM (data not shown).

The binding capacity of a large panel of monoclonal IgM for $\mathrm{pFv}$ was evaluated by direct binding ELISA (Fig. 1). ELISA studies demonstrated that different IgM have a wide range of reactivities with $\mathrm{pFv}$, and $42.3 \%(21 / 52)$ of this panel of monoclonal IgM, including $4 / 21 \mathrm{~V}_{\mathrm{H}} 1,0 / 1 \mathrm{~V}_{\mathrm{H}} 2,13 / 14 \mathrm{~V}_{\mathrm{H}} 3,1 / 11$ $\mathrm{V}_{\mathrm{H}} 4,0 / 1 \mathrm{~V}_{\mathrm{H}} 5$, and $3 / 4 \mathrm{~V}_{\mathrm{H}} 6$ IgM, displayed significant ELISA reactivity with $\mathrm{pFv}$. Binding specificity was confirmed by demonstration that soluble $\mathrm{pFv}$ inhibited the interaction with solid phase $\mathrm{pFv}$ (data not shown). IgM from the $\mathrm{V}_{\mathrm{H}} 1$ and $\mathrm{V}_{\mathrm{H}} 4$ families with $\mathrm{pFv}$ binding activity generally had weaker $\mathrm{pFv}$ binding activity than displayed by the $\mathrm{V}_{\mathrm{H}} 3$ and $\mathrm{V}_{\mathrm{H}} 6$ IgM binders. Binding to a panel of control antigens was also tested, but the IgM were uniformly nonreactive except for the $\mathrm{V}_{\mathrm{H}} 6 \mathrm{IgM}$, L16, which had significant binding activity with orosomucoid, a control sialoprotein preparation.

Inhibition of polyclonal IgM pFv binding by monoclonal IgM. In competitive binding studies, three $\mathrm{V}_{\mathrm{H}} 3$ IgM, 18/2, Kim4.6, and Huab2-3, were potent inhibitors. The $\mathrm{V}_{\mathrm{H}} 3 \mathrm{IgM}$ Huab14-3, the $\mathrm{V}_{\mathrm{H}} 6$ IgM L16, and polyclonal IgM had intermediate inhibition capacity. The $\mathrm{V}_{\mathrm{H}} 1$ IgM KAS was the weakest inhibitor (Fig. 2). At higher concentrations, the five different monoclonal IgM were each able to significantly inhibit (75$97 \%$ ) pFv binding by polyclonal IgM (Fig. 2). Of those tested, the best inhibitors were the IgM- $\kappa 18 / 2$ and the IgM- $\lambda$ KIM4.6, which use $\mathrm{V}_{\mathrm{H}} 3$ regions encoded by the germline configuration of the $\mathrm{V}_{\mathrm{H}} 26 \mathrm{c} / \mathrm{V} 3-23$ and 1.9III/V3-30 gene segments, respectively (23-25). Presumably because it is capable of only monovalent binding interactions, the monoclonal IgG- $\lambda$ Fab JGSpA3-08 (9) encoded by a different rearrangement of the $V_{H} 26 c / V 3-23$ gene was a $\sim 30$-fold weaker inhibitor. Polyclonal IgG Fab was by far the weakest of the inhibitors tested, and IgG Fc had no detectable inhibition capacity. The demonstration that monoclonal antibodies from different $\mathrm{V}_{\mathrm{H}}$ families can each nearly completely inhibit binding of polyclonal IgM, which represents a mixture of IgM, suggests that Fab-mediated binding is not due to recognition of a multitude of conventional epitopes on $\mathrm{pFv}$, but derives from interactions with a common or closely adjacent Fab-binding site. Polyclonal IgM contains subpopulations of strong and weak (and non-) pFv binders (illustrated in Fig. 1), which is presumably the basis by which low concentrations (i.e., $0.01-0.1 \mathrm{ng} / \mathrm{ml}$ ) of certain monoclonal $\mathrm{V}_{\mathrm{H}} 3 \mathrm{IgM}$ with strong $\mathrm{pFv}$ binding activity caused significant inhibition of the binding of a portion of polyclonal IgM to $\mathrm{pFv}$. In other studies, IgM and Fab from different $V_{H}$ families, and with dissimilar L chain isotypes, could also inhibit the binding of each other to $\mathrm{pFv}$ (data not shown).

Binding affinities measured by surface plasmon resonance. Based on direct binding and competition ELISA, five IgM with stronger $\mathrm{pFv}$ binding interactions were selected for further evaluation. Based on the structures of $\mathrm{pFv}$ and intact IgM, these appear to represent multivalent binding interactions of strong avidity. Despite the use of diverse $V_{H}$ regions (Fig. 3), surface plasmon resonance studies indicated that the $\mathrm{V}_{\mathrm{H}} 6$ IgM L16 interacts with $\mathrm{pFv}$ with an apparent association constant $\left(K_{\mathrm{a}}\right)$ of $8.8 \times 10^{7} \mathrm{M}^{-1}$, and the four $\mathrm{V}_{\mathrm{H}} 3 \mathrm{IgM}$, Hum2-3, Hum 14$3,18 / 2$, and KIM4.6, bind with a $K_{\mathrm{a}}$ of $0.11-6.7 \times 10^{8} \mathrm{M}^{-1}$ (Table I). Consistent with the results of the competitive binding assays, the IgM 18/2 and KIM4.6 displayed the strongest binding interactions with $\mathrm{pFv}$. The $\mathrm{V}_{\mathrm{H}}$ region of the IgM- $\kappa \mathrm{Fab}$ JMSpA3-15 expresses the germline configuration of $\mathrm{V}_{\mathrm{H}} 26 \mathrm{c} /$ V3-23, which differs by only 4 amino acids in this portion from the IgG- $\lambda$ Fab JGSpA3-08 (Fig. 3). These Fab, which are capable of only monovalent interactions, bind $\mathrm{pFv}$ with $K_{\mathrm{a}}$ values of 1.9 and $3.5 \times 10^{6} \mathrm{M}^{-1}$, respectively.

Analysis of library composition. Combinatorial Ig phagedisplay libraries were used to investigate the $\mathrm{pFv}$ binding capacity of different IgM Fab and IgG Fab. Colony hybridization studies documented that the unselected JM library contained $19 \% \mathrm{~V}_{\mathrm{H}} 1,0 \% \mathrm{~V}_{\mathrm{H}} 2,22 \% \mathrm{~V}_{\mathrm{H}} 3,39 \% \mathrm{~V}_{\mathrm{H}} 4,0 \% \mathrm{~V}_{\mathrm{H}} 5$, and $7 \%$ $\mathrm{V}_{\mathrm{H}} 6$ (with $\sim 13 \%$ unidentified) $\mu$ rearrangements (Table II). Although appropriate $V_{H}$ primers were used, $V_{H} 2$ family $F a b$ clones were not detected in the library. By ELISA, of 45 IgM clones evaluated from the unselected library, $10(22 \%)$ had a significant binding interaction with $\mathrm{pFv}$ (data not shown).

In an earlier report (9), the unselected JG library was shown to contain $26 \% \mathrm{~V}_{\mathrm{H}} 1,26 \% \mathrm{~V}_{\mathrm{H}} 3$, and $26 \% \mathrm{~V}_{\mathrm{H}} 4 \gamma$ rearrangements (other $\mathrm{V}_{\mathrm{H}}$ families were not assessed). A total of $21 \mathrm{IgG}$ Fab 


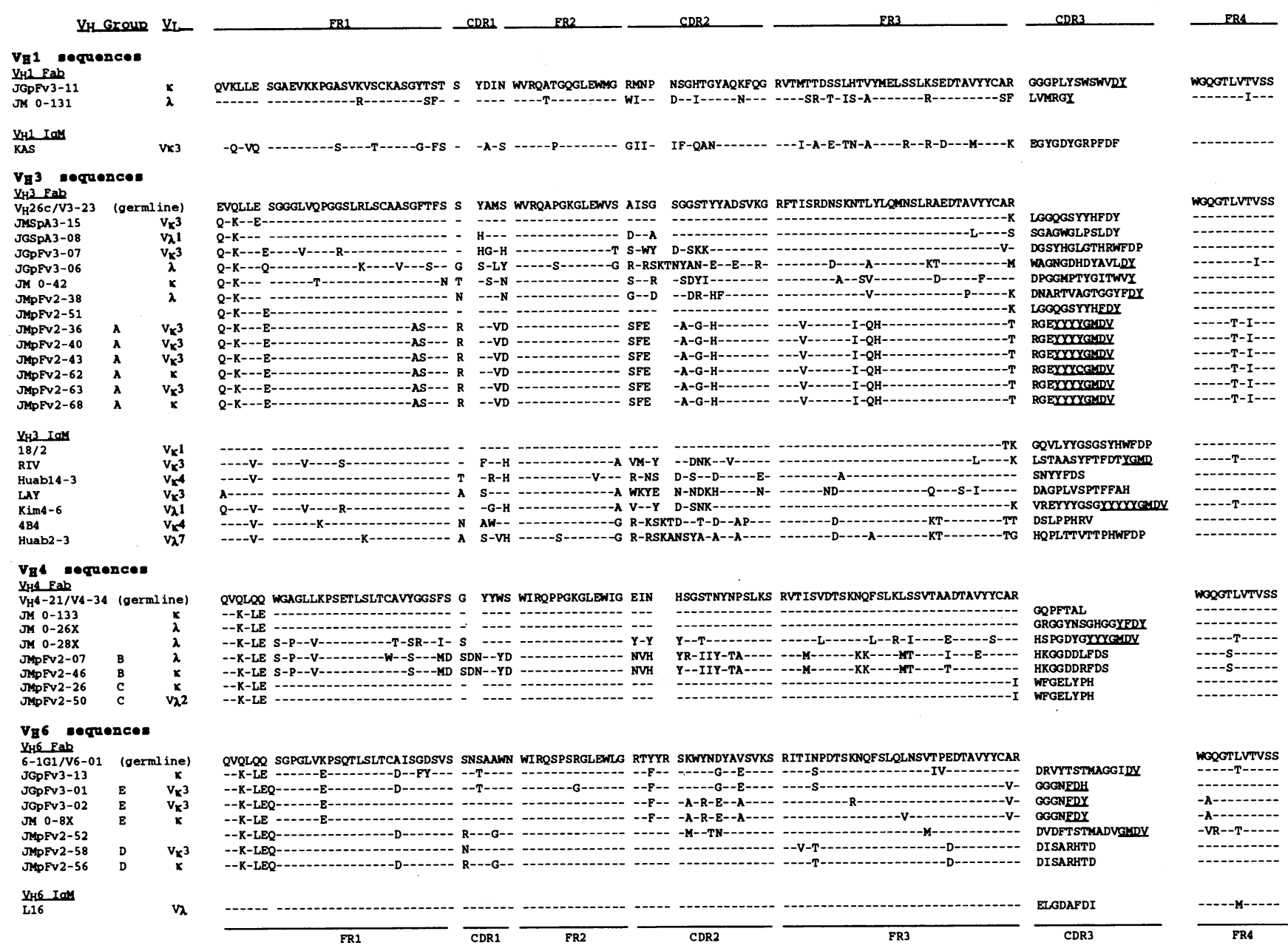

Figure 3. $\mathrm{V}_{\mathrm{H}}$ regions of antibodies that bind $\mathrm{pFv}$. $\mathrm{V}_{\mathrm{H}}$ region sequences from intact IgM antibodies with strong reactivity for $\mathrm{pFv}$ are included. All antibodies contain $\mathrm{H}$ and $\mathrm{L}$ chains and bind $\mathrm{pFv}$, with the exception of $\mathrm{JMpFv} 2-51$, which was defective owing to an absent $\mathrm{L}$ chain. The germline gene segments $\mathrm{V}_{\mathrm{H}} 26 / \mathrm{V} 3-23(29,30), \mathrm{V}_{\mathrm{H}} 4-21 / \mathrm{V} 4-34$ (31), and 6-1G1/V6-01 (33) are included for comparison. Residues identical to those used in the master sequence are indicated by a dash. The first framework sequences encoded by the oligonucleotide primers are underlined. Residues in the CDR3 that are contributed by the $\mathrm{J}_{\mathrm{H}}$ gene segment are underlined. The portion of the rearranged genes upstream of these primers is part of the vector. Subdomains were assigned as described by Kabat et al. (36) and modified by Chothia and Lesk (37). These sequence data are available from EMBL/GenBank/DDBJ under accession numbers U21248-U21272 and L06102 for Huab2-3 and L06101 for Huab14-3.

clones from the unselected JG library were evaluated, but only $2(9.5 \%)$ IgG Fab were found to have significant binding capacity for $\mathrm{pFv}$ (data not shown). Fab with $\mathrm{pFv}$ binding capacities were less frequent in the unselected IgG library than in the unselected IgM library, but this difference was not statistically significant (Fisher exact test, $P<0.21$ ), likely owing to the limited number of clones examined.

Biopanning of the combinatorial libraries for $p F v$ binders. The JM library was subjected to two rounds of panning with $\mathrm{pFv}$, and 21 representative clones from the JMpFv2 library were evaluated. With the exception of JMpFv2-51, which was defective owing to an absent $\mathrm{L}$ chain gene, all bound $\mathrm{pFv}$ (data not shown), indicating that panning resulted in significant selection of $\mathrm{pFv}$ binders (Fisher exact test $P<0.0001$ ). Colony hybridization studies indicated a sequential selection for $\mathrm{V}_{\mathrm{H}} 3$ and $\mathrm{V}_{\mathrm{H}} 6$ clones (Table II). The JG library was subjected to three rounds of panning with pFv. 12 representative clones from the resultant library were evaluated, and 7 IgG Fab clones had significant $\mathrm{pFv}$ binding activity (data not shown).

$V$ region sequence analyses of $F a b$ with $p F v$ binding capac ity. The complete DNA sequences were determined for the $V_{H}$ regions of six IgM Fab clones with $\mathrm{pFv}$ binding activity obtained from the unselected JM library, which included JM 0$131\left(\mathrm{~V}_{\mathrm{H}} 1\right)$, JM 0-42 $\left(\mathrm{V}_{\mathrm{H}} 3\right) \mathrm{JM}$ 0-28X $\left(\mathrm{V}_{\mathrm{H}} 4\right)$, JM 0-26X $\left(\mathrm{V}_{\mathrm{H}} 4\right)$, JM 0-133 $\left(\mathrm{V}_{\mathrm{H}} 4\right)$, and JM 0-8X $\left(\mathrm{V}_{\mathrm{H}} 6\right)$. From sequence analysis, all were derived from independent $\mathrm{V}_{\mathrm{H}}$ rearrangements (Fig. 3; Table III). Included in Fig. 5 are the $V_{H}$ sequences available for nine intact IgM with $\mathrm{pFv}$ binding capacity.

The $\mathrm{V}_{\mathrm{H}}$ sequences of 15 representatives of the JMpFv2 library obtained after two rounds of selection with $\mathrm{pFv}$ were also determined (Fig. 3). These $V_{H}$ genes appear to derive from only seven different rearrangements. JMpFv2-51 $\left(\mathrm{V}_{\mathrm{H}} 3\right)$, JMpFv2-38 $\left(\mathrm{V}_{\mathrm{H}} 3\right)$, and $\mathrm{JMpFv} 2-52\left(\mathrm{~V}_{\mathrm{H}} 6\right)$ are the only single representatives of their respective $V_{H}$ gene rearrangements, and the other $12 \mathrm{~V}_{\mathrm{H}}$ regions can be grouped based on the usage of identical or nearly identical gene rearrangements: $\mathrm{V}_{\mathrm{H}}$ group $\mathrm{A}, \mathrm{JMpFv} 2-$ $36 / 40 / 43 / 62 / 63 / 68\left(\mathrm{~V}_{\mathrm{H}} 3\right) ; \mathrm{V}_{\mathrm{H}}$ group $\mathrm{B}$, JMpFv2-07/46 $\left(\mathrm{V}_{\mathrm{H}} 4\right) ; \mathrm{V}_{\mathrm{H}}$ group $\mathrm{C}$, JMpFv2-26/50 $\left(\mathrm{V}_{\mathrm{H}} 4\right)$; and $\mathrm{V}_{\mathrm{H}}$ group $\mathrm{D}$, JMpFv2-58/56 $\left(\mathrm{V}_{\mathrm{H}} 6\right)$.

A total of six $\mathrm{V}_{\mathrm{H}}$ region sequences were determined for representative clones from the JG library obtained after three rounds of biopanning with $\mathrm{pFv}$ (Fig. 3). Of these, four, JGpFv3- 
Table I. Binding Kinetics of Antibodies for Protein Fv

\begin{tabular}{|c|c|c|c|c|c|c|c|}
\hline Ig & $\mathrm{V}_{\mathrm{H}}$ usage & $V_{L}$ usage & $\mathrm{Ag}^{*}$ & Isotype $^{\ddagger}$ & Reference & & Binding constants \\
\hline \multicolumn{8}{|c|}{ Fab fragments (monomeric) } \\
\hline \multirow[t]{4}{*}{ JMSpA3-15 } & $\mathrm{V}_{\mathrm{H}} 3 \mathrm{~V}_{\mathrm{H}} 26 \mathrm{c} / \mathrm{V} 3-23(100 \%)$ & $\mathrm{V}_{k} 3$ & SpA & IgM Fab & & $k_{\text {on }}$ & $5.96 \times 10^{4} \mathrm{M}^{-1} \mathrm{~s}^{-1}$ \\
\hline & & & & & & $k_{\text {off }}$ & $3.1 \times 10^{-3} \mathrm{~s}^{-1}$ \\
\hline & & & & & & $K_{\mathrm{a}}$ & $1.92 \times 10^{6} \mathrm{M}^{-1}$ \\
\hline & & & & & & $K_{\mathrm{d}}$ & $5.2 \times 10^{-7} \mathrm{M}$ \\
\hline \multirow[t]{4}{*}{ JGSpA3-08 } & $\mathrm{V}_{\mathrm{H}} 3 \mathrm{~V}_{\mathrm{H}} 26 \mathrm{c} / \mathrm{V} 3-23(94.8 \%)$ & $V_{\lambda} 1$ & SpA & IgG Fab & (9) & $k_{\text {on }}$ & $9.8 \times 10^{3} \mathrm{M}^{-1} \mathrm{~s}^{-1}$ \\
\hline & & & & & & $k_{\text {off }}$ & $2.7 \times 10^{-4} \mathrm{~s}^{-1}$ \\
\hline & & & & & & $K_{\mathrm{a}}$ & $3.5 \times 10^{6} \mathrm{M}^{-1}$ \\
\hline & & & & & & $K_{\mathrm{d}}$ & $2.9 \times 10^{-7} \mathrm{M}$ \\
\hline \multicolumn{8}{|l|}{ IgM (polymeric) } \\
\hline \multirow[t]{4}{*}{$18 / 2$} & $\mathrm{~V}_{\mathrm{H}} 3 \mathrm{~V}_{\mathrm{H}} 26 \mathrm{c} / \mathrm{V} 3-23(100 \%)$ & $\mathrm{V}_{\kappa} 1$ & DNA & $\operatorname{IgM}$ & (23) & $k_{\text {on }}$ & $3.75 \times 10^{4} \mathrm{M}^{-1} \mathrm{~s}^{-1}$ \\
\hline & & & & & & $k_{\text {off }}$ & $2.5 \times 10^{-4} \mathrm{~s}^{-1}$ \\
\hline & & & & & & $K_{\mathrm{a}}$ & $1.5 \times 10^{8} \mathrm{M}^{-1}$ \\
\hline & & & & & & $K_{\mathrm{d}}$ & $6.7 \times 10^{-9} \mathrm{M}$ \\
\hline \multirow[t]{4}{*}{ KIM4.6 } & $\mathrm{V}_{\mathrm{H}} 3$ 1.9III/V3-30 (100\%) & $\mathrm{V}_{\lambda} 1$ & DNA & $\operatorname{IgM}$ & (25) & $k_{\text {on }}$ & $4.3 \times 10^{4} \mathrm{M}^{-1} \mathrm{~s}^{-1}$ \\
\hline & & & & & & $k_{\text {off }}$ & $6.4 \times 10^{-5} \mathrm{~s}^{-1}$ \\
\hline & & & & & & $K_{\mathrm{a}}$ & $6.7 \times 10^{8} \mathrm{M}^{-1}$ \\
\hline & & & & & & $K_{\mathrm{d}}$ & $1.5 \times 10^{-9} \mathrm{M}$ \\
\hline \multirow[t]{4}{*}{ Hum2-3 } & $\mathrm{V}_{\mathrm{H}} 3$ MTGL/V3-73 (90\%) & $V_{\lambda} 7$ & PPS-3 & IgM & (26) & $k_{\text {on }}$ & $3.4 \times 10^{3} \mathrm{M}^{-1} \mathrm{~s}^{-1}$ \\
\hline & & & & & & $k_{\text {off }}$ & $2.4 \times 10^{-4} \mathrm{~s}^{-1}$ \\
\hline & & & & & & $K_{\mathrm{a}}$ & $1.4 \times 10^{7} \mathrm{M}^{-1}$ \\
\hline & & & & & & $K_{\mathrm{d}}$ & $1.1 \times 10^{-8} \mathrm{M}$ \\
\hline \multirow[t]{4}{*}{ Hum14-3 } & $\mathrm{V}_{\mathrm{H}} 3 \mathrm{H} 11(97 \%)$ & $V_{k} 4$ & PPS-3 & IgM & (26) & $k_{\text {on }}$ & $5.0 \times 10^{3} \mathrm{M}^{-1} \mathrm{~s}^{-1}$ \\
\hline & & & & & & $k_{\text {off }}$ & $4.5 \times 10^{-4} \mathrm{~s}^{-1}$ \\
\hline & & & & & & $K_{\mathrm{a}}$ & $1.1 \times 10^{7} \mathrm{M}^{-1}$ \\
\hline & & & & & & $K_{\mathrm{d}}$ & $9.1 \times 10^{-8} \mathrm{M}$ \\
\hline \multirow[t]{4}{*}{ L16 } & $\mathrm{V}_{\mathrm{H}} 6$ 6-1R1/V6-01 (100\%) & $\mathrm{V}_{\lambda}$ & Polyspecific & IgM & (27) & $k_{\text {on }}$ & $1.76 \times 10^{4} \mathrm{M}^{-1} \mathrm{~s}^{-1}$ \\
\hline & & & & & & $k_{\text {off }}$ & $2.0 \times 10^{-4} \mathrm{~s}^{-1}$ \\
\hline & & & & & & $K_{\mathrm{a}}$ & $8.8 \times 10^{7} \mathrm{M}^{-1}$ \\
\hline & & & & & & $K_{\mathrm{d}}$ & $1.1 \times 10^{-8} \mathrm{M}$ \\
\hline
\end{tabular}

The kinetics of binding interactions with $\mathrm{pFv}$ were measured by surface plasmon resonance determinations using the BIAcore apparatus (see Methods). The coefficients of correlation $(r)$ were all $>0.96$. Values were reproducible to within $20 \%$. Upon testing, binding of $p F v$ by the $\mathrm{V}_{\mathrm{H}} 1$ IgM KAS and the IgM Fab JM 0-8X $\left(\mathrm{V}_{\mathrm{H}} 6\right)$, JM 0-42 $\left(\mathrm{V}_{\mathrm{H}} 3\right)$, JM 0-133 $\left(\mathrm{V}_{\mathrm{H}} 4\right)$, and JMpFv2-43 $\left(\mathrm{V}_{\mathrm{H}} 3\right)$ was also detected by surface plasmon resonance, but binding coefficients could not be accurately determined owing to relative affinity and limitations of antibody concentrations. $*$ The antigen binding specificity for which the antibody was originally selected. PPS-3, pneumococcal polysaccharide type $3 .{ }^{\ddagger}$ Isotype of the antibody.

$11\left(\mathrm{~V}_{\mathrm{H}} 1\right), \mathrm{JGpFv} 3-07\left(\mathrm{~V}_{\mathrm{H}} 3\right), \mathrm{JGpFv3}-06\left(\mathrm{~V}_{\mathrm{H}} 3\right)$, and JGpFv3$13\left(\mathrm{~V}_{\mathrm{H}} 6\right)$, represent single and unrelated $\mathrm{V}_{\mathrm{H}}$ rearrangements. The other two, JGpFv3-01 and JGpFv3-02, were amplified by different upstream primers but appear to be intraclonal variants

Table II. $V_{H}$ Family Distribution in the Combinatorial Libraries

\begin{tabular}{lcccrcrl}
\hline Library & $\mathrm{V}_{\mathrm{H} 1}$ & $\mathrm{~V}_{\mathrm{H}} 2$ & $\mathrm{~V}_{\mathrm{H}} 3$ & $\mathrm{~V}_{\mathrm{H}} 4$ & $\mathrm{~V}_{\mathrm{H}} 5$ & $\mathrm{~V}_{\mathrm{H}} 6$ & Total \\
\hline JM 0 & $19 *$ & 0 & 22 & 39 & 0 & 7 & $87^{\S}$ \\
JMpFv1 & 13 & 0 & 19 & 22 & 2 & 15 & 71 \\
JMpFv2 & 0.5 & 0 & 47 & 9 & 0 & 28 & 84.5
\end{tabular}

These data represent results of hybridization of membrane lifts of bacterial colonies with $150-250$ colonies per plate. JM 0 represents the unselected IgM Fab library, and JMpFv1 and JMpFv2 are the libraries obtained after one or two sequential rounds of selection by the $\mathrm{pFv}$ protein. Data are presented as the percentage of colonies that hybridized with a $\mu$-specific probe. ${ }^{*}$ Controls included in each study were plasmids with $\mathrm{V}_{\mathrm{H}}$ genes of all known families. In each survey certain colonies were unidentified, either because they did not contain $\mathrm{V}_{\mathrm{H}}$ genes or presumably because $\mathrm{V}_{\mathrm{H}}$ sequence variations abolished hybridization. of the same $V_{H} 6$ rearrangement and are therefore designated group E. JM 0-8X, a $\mu \mathrm{V}_{\mathrm{H}} 6$ rearrangement from the unselected JM library, was likely created by amplification with different upstream and downstream primers but appears to be clonally related to the $\gamma$ chains in JGpFv3-01 and JGpFv3-02, so it has also been included in group $E$. The $\mathrm{V}_{\mathrm{H}}$ gene sequence of $\mathrm{JM}$ 0-8X also shares most mutations present in the JGpFv3-02. This pattern, in which a $\mu \mathrm{V}_{\mathrm{H}} 6$ sequence (JM 0-8X) has accumulated more somatic mutations than a clonally related $\gamma \mathrm{V}_{\mathrm{H}} 6$ rearrangement ( JGpFv3-01), has previously been described (28). By comparisons of $V_{H}$ rearrangement sequences with the GenBank data base, the closest known $\mathrm{V}_{\mathrm{H}}$ germline genes were identified (Table III).

Among the $V_{H}$ sequences of selected $\mathrm{Fab}$, each of the members of $\mathrm{V}_{\mathrm{H}}$ groups $\mathrm{B}, \mathrm{D}$, and $\mathrm{E}$ contains a level of sequence variation that greatly exceeded our experimental Taq polymerase infidelity error $(<1 / 1,500$ nucleotides $)$, which indicates that they were independently derived from in vivo clonally related $\mathrm{B}$ cells and therefore must have been independently selected by $\mathrm{pFv}$. Whereas the $\mathrm{V}_{\mathrm{H}}$ regions of group $\mathrm{C}$ are identical, the associated $\mathrm{L}$ chains are encoded by a $\kappa$ gene and a $\lambda$ 


\begin{tabular}{|c|c|c|c|c|c|c|c|c|c|c|c|c|c|c|c|c|c|c|c|}
\hline & & & & & & & & FR & & $\mathrm{CD}$ & & FR & & CDR & & FR & & & \\
\hline & Primer & $\begin{array}{c}V_{\mathrm{H}} \\
\text { family }\end{array}$ & Nearest $V_{\mathrm{H}} *$ & Reference & $\begin{array}{c}V_{H} \\
\text { group }\end{array}$ & $\begin{array}{c}\text { DNA } \\
\text { homology }\end{array}$ & $\begin{array}{c}\text { Protein } \\
\text { homology }\end{array}$ & $\mathbf{R}$ & $s$ & $\mathbf{R}$ & $\mathrm{s}$ & $R$ & $s$ & $\mathbf{R}$ & $\mathrm{s}$ & $\mathbf{R}$ & $\mathrm{s}$ & $\mathbf{J}_{\mathrm{H}}$ & $\begin{array}{c}V_{L} \\
\text { usage }\end{array}$ \\
\hline Unselected & & & & & & & & & & & & & & & & & & & \\
\hline JM IgM li & & & & & & & & & & & & & & & & & & & \\
\hline JM 0-131 & $1 \mathrm{f} / 3 \mathrm{f}$ & 1 & DP-15/V1-08 & (29) & & $93.5 \%$ & $89.9 \%$ & 2 & 2 & 0 & 2 & 1 & 0 & 4 & 3 & 2 & 1 & $4 b$ & $\lambda$ \\
\hline JM 0-42 & $1 \mathrm{f} / 3 \mathrm{f}$ & 3 & $\mathrm{~V}_{\mathrm{H}} 26 \mathrm{c} / \mathrm{V} 3-23$ & $(24,30)$ & & $96.3 \%$ & $91.3 \%$ & 2 & 0 & 1 & 0 & 0 & 0 & 2 & 1 & 3 & 1 & 4 & $\kappa$ \\
\hline JM 0-26X & 4gs & 4 & 4-21/V4-34 & (31) & & $100 \%$ & $100 \%$ & 0 & 0 & 0 & 0 & 0 & 0 & 0 & 0 & 0 & 0 & $4 b$ & $\lambda$ \\
\hline JM 0-28X & $6 f$ & 4 & $4-11 / V 4-59$ & (31) & & $94.3 \%$ & $91.3 \%$ & 1 & 2 & 0 & 0 & 0 & 1 & 1 & .1 & 6 & 3 & 6 & $\lambda$ \\
\hline & & & T23-9* & (32) & & $95 \%$ & $91.3 \%$ & 1 & 2 & 0 & 0 & 0 & 1 & 1 & 1 & 6 & 1 & 6 & $\lambda$ \\
\hline JM 0-133 & 4gs & 4 & $4-21 / \mathrm{V} 4-34$ & (31) & & $100 \%$ & $100 \%$ & 0 & 0 & 0 & 0 & 0 & 0 & 0 & 0 & 0 & 0 & 4 & $\kappa$ \\
\hline JM 0-8X & $6 f$ & 6 & 6-1G1/V6-01 & (33) & $\mathrm{D}$ & $95.6 \%$ & $92.4 \%$ & 1 & 0 & 0 & 0 & 0 & 0 & 5 & 4 & $1^{\ddagger}$ & 1 & 4 & $\kappa$ \\
\hline Selected & & & & & & & & & & & & & & & & & & & \\
\hline J JM IgM li & & & & & & & & & & & & & & & & & & & \\
\hline JMpFv2-38 & $1 \mathrm{f} / 3 \mathrm{f}$ & 3 & $V_{H} 26 c / V 3-23$ & $(24,30)$ & & $95.2 \%$ & $88.8 \%$ & 0 & 0 & 2 & 0 & 0 & 1 & 6 & 1 & 2 & 1 & $4 \mathrm{~b}$ & $\lambda$ \\
\hline JMpFv2-36 & $3 a$ & 3 & $\mathrm{~V}_{\mathrm{H}} 26 \mathrm{c} / \mathrm{V} 3-23$ & $(24,30)$ & A & $87.1 \%$ & $82.2 \%$ & 2 & 5 & 3 & 2 & 0 & 2 & 7 & 6 & 4 & 3 & 6 & $\mathrm{~V}_{k} 3^{8}$ \\
\hline JMpFv2-40 & $3 a$ & 3 & $\mathrm{~V}_{\mathrm{H}} 26 \mathrm{c} / \mathrm{V} 3-23$ & $(24,30)$ & A & $86.8 \%$ & $82.2 \%$ & 2 & 5 & 3 & 2 & 0 & 2 & 7 & 6 & 4 & 4 & 6 & $\mathrm{~V}_{\kappa} 3^{8}$ \\
\hline JMpFv2-43 & $3 a$ & 3 & $\mathrm{~V}_{\mathrm{H}} 26 \mathrm{c} / \mathrm{V} 3-23$ & $(24,30)$ & A & $86.8 \%$ & $82.2 \%$ & 2 & 5 & 3 & 2 & 0 & 2 & 7 & 6 & 4 & 4 & 6 & $\mathrm{~V}_{\kappa} 3^{8}$ \\
\hline JMpFv2-62 & $3 a$ & 3 & $V_{H} 26 c / V 3-23$ & $(24,30)$ & $\mathrm{A}$ & $87.1 \%$ & $82.2 \%$ & 2 & 5 & 3 & 2 & 0 & 2 & 7 & 6 & 4 & 3 & 6 & $\kappa$ \\
\hline JMpFv2-63 & $3 a$ & 3 & $\mathrm{~V}_{\mathrm{H}} 26 \mathrm{c} / \mathrm{V} 3-23$ & $(24,30)$ & A & $86.8 \%$ & $82.2 \%$ & 2 & 5 & 3 & 2 & 0 & 2 & 7 & 6 & 4 & 4 & 6 & $\mathrm{~V}_{k} 3^{8}$ \\
\hline JMpFv2-68 & $3 a$ & 3 & $\mathrm{~V}_{\mathrm{H}} 26 \mathrm{c} / \mathrm{V} 3-23$ & $(24,30)$ & A & $86.8 \%$ & $82.2 \%$ & 2 & 5 & 3 & 2 & 0 & 2 & 7 & 6 & 4 & 4 & 6 & $\kappa$ \\
\hline JMpFv2-51 & $3 a$ & 3 & $V_{H} 26 c / V 3-23$ & $(24,30)$ & & $100 \%$ & $100 \%$ & 0 & 0 & 0 & 0 & 0 & 0 & 0 & 0 & 0 & 0 & $4 b$ & \\
\hline JMpFv2-07 & $2 \mathrm{f} / 4 \mathrm{f}$ & 4 & 4-18/V4-39 & (31) & B & $85.3 \%$ & $75.0 \%$ & 4 & 3 & 4 & 3 & 0 & 3 & 8 & 3 & 7 & 5 & 4 & $\lambda$ \\
\hline JMpFv2-46 & $2 f / 4 f$ & 4 & $4-18 / V 4-39$ & (31) & B & $86.8 \%$ & $78.3 \%$ & 3 & 3 & 4 & 3 & 0 & 3 & 7 & 4 & 6 & 4 & 4 & $\kappa$ \\
\hline JMpFv2-50 & $4 \mathrm{gs}$ & 4 & $4-21 / V 4-34$ & (31) & $\mathrm{C}$ & $100 \%$ & $100 \%$ & 0 & 0 & 0 & 0 & 0 & 0 & 0 & 0 & 0 & 0 & 4 & $\mathrm{~V}_{\lambda} 2$ \\
\hline JMpFv2-26 & 4gs & 4 & 4-21/V4-34 & (31) & $\mathrm{C}$ & $100 \%$ & $100 \%$ & 0 & 0 & 0 & 0 & 0 & 0 & 0 & 0 & 0 & 0 & 4 & $\kappa$ \\
\hline JMpFv2-52 & $6 a$ & 6 & 6-1G1/V6-01. & (33) & & $96.8 \%$ & $92.6 \%$ & 1 & 0 & 2 & 0 & 0 & 0 & 3 & 1 & 1 & 1 & 6 & $\kappa$ \\
\hline JMpFv2-56 & $6 a$ & 6 & 6-1G1/V6-01 & (33) & D & $97.5 \%$ & $94.7 \%$ & 1 & 0 & 2 & 0 & 0 & 0 & 0 & 1 & 2 & 1 & 6 & $\kappa$ \\
\hline JMpFv2-58 & $6 a$ & 6 & 6-1G1/V6-01 & (33) & D & $97.8 \%$ & $95.6 \%$ & 0 & 0 & 1 & 0 & 0 & 0 & 0 & 2 & 3 & 2 & 6 & $\mathrm{~V}_{\kappa} 3$ \\
\hline Selected & & & & & & & & & & & & & & & & & & & \\
\hline JG IgG lit & & & & & & & & & & & & & & & & & & & \\
\hline JGpFv3-11 & $1 \mathrm{f} / 3 \mathrm{f}$ & 1 & DP-15/V1-08 & (29) & & $94.8 \%$ & $89.1 \%$ & 1 & 0 & 0 & 0 & 0 & 0 & 2 & 1 & 7 & 3 & 4 & $\kappa$ \\
\hline JGpFv3-06 & $1 \mathrm{a}$ & 3 & MTGL/V3-73 & (34) & & $95.5 \%$ & $90.2 \%$ & 2 & 3 & 2 & 0 & 0 & 0 & 5 & 0 & 0 & 1 & $4 b$ & $\lambda$ \\
\hline JGpFv3-07 & $3 a$ & 3 & hv3019/V3-33 & (35) & & $97.3 \%$ & $95.6 \%$ & 0 & 0 & 1 & 1 & 1 & 0 & 2 & 1 & 0 & 2 & 1 & $\mathrm{~V}_{\kappa} 3$ \\
\hline JGpFv3-13 & $6 \mathrm{a} / 6 \mathrm{f}$ & 6 & 6-1G1/V6-01 & (33) & & $91.8 \%$ & $88.0 \%$ & 4 & 0 & 1 & 0 & 0 & 0 & 3 & 2 & 3 & 5 & 6 & $\kappa$ \\
\hline JGpFv3-01 & $6 \mathrm{a} / 6 \mathrm{f}$ & 6 & 6-1G1/V6-01 & (33) & $\mathrm{E}$ & $95.2 \%$ & $91.3 \%$ & 2 & 0 & 1 & 0 & 1 & 1 & 3 & 2 & 1 & 1 & 1 & $V_{\kappa} 3$ \\
\hline JGpFv3-02 & $6 \mathrm{a} / 6 \mathrm{f}$ & 6 & 6-1G1/V6-01 & (33) & E & $93.7 \%$ & $92.3 \%$ & 1 & 0 & 0 & 0 & 0 & 0 & 5 & 4 & $1^{\ddagger}$ & 2 & 4 & $V_{\kappa} 3$ \\
\hline
\end{tabular}

* Comparison with the closest known germline $\mathrm{V}_{\mathrm{H}}$ gene segment, except in the case of T23-9, which represents a rearranged gene. Germline genes are designated as originally named and by the nomenclature of Matsuda et al. (64). ${ }^{\ddagger}$ Subdomains are assigned as described by Kabat et al. (36) and modified by Chothia and Lesk (37); these assignments have been modified based on crystallographic data, and calculations of homology were performed omitting the contribution of the upstream primer and ending with the codon for the terminal cysteine. $R$ represents replacement mutations. $S$ represents silent mutations. ${ }^{8} T h e \mathrm{~V}_{k} 3$ genes encoding the $\mathrm{L}$ chains of group A are identical except for a single mutation in JMpFv2-40. Based on $\mathrm{V}_{\mathrm{H}}$ and $\mathrm{V}_{\mathrm{L}}$ homology, these likely represent duplications of the same phagemid clone. By similar criteria, the individual members of groups $\mathrm{B}, \mathrm{C}$, and $\mathrm{E}$ were probably different clones that were independently selected.

gene (Table III). Taken together, these data indicate that in many cases independent antibody clones with identical or highly similar $\mathrm{V}_{\mathrm{H}}$ regions were recurrently selected, presumably based on preferential $\mathrm{pFv}$ binding activity. These data further support the overall impression that $\mathrm{pFv}$ binding is $\mathrm{V}_{\mathrm{H}}$ dependent, with limited, if any, influence from the $V_{L}$ region.

Analyses of the CDR3 of the Fab selected from the phagedisplay libraries revealed a remarkable consistency. While there were no recurrently used sequence motifs or charge-hydrophilicity distributions, there was evidence of selection based on the size of the CDR3. This trend was even more pronounced among the $V_{H}$ genes that were repeatedly represented (and therefore assigned to $\mathrm{V}_{\mathrm{H}}$ groups $\mathrm{A}-\mathrm{E}$ ). The CDR3 sizes of these 15 sequences exhibit a restricted range of $7-11(9.1 \pm 1.8$, mean $\pm S D$ ) and are all smaller than the mean size of $\mathrm{V}_{\mathrm{H}} \mathrm{CDR} 3$ expressed in the adult repertoire $(38,39)$.

\section{Discussion}

The current report investigates the structural basis for antibody binding of protein Fv, a human sialoprotein with unique immunologic properties. These studies confirm that among antibody populations, the frequency of $\mathrm{pFv}$ binders is many orders of magnitude greater than occurs for the expression of a conventional antigen binding specificity. Within the panel of monoclonal IgM, pFv binding capacity was expressed by only a small proportion of $\mathrm{V}_{\mathrm{H}} 1$ and $\mathrm{V}_{\mathrm{H}} 4$ antibodies $(<20 \%$ and $<10 \%$, respectively), whereas almost all $\mathrm{V}_{\mathrm{H}} 3$ and $\mathrm{V}_{\mathrm{H}} 6$ IgM bound $\mathrm{pFv}$. 
Significantly, among the five $\mathrm{V}_{\mathrm{H}} 3 \mathrm{IgM}$ antibodies studied in detail, antibodies directly encoded by the germline $\mathrm{V}_{\mathrm{H}} 26 \mathrm{c} / \mathrm{V} 3-$ $23,1.9 \mathrm{III} / \mathrm{V} 3-30$, and $\mathrm{V}_{\mathrm{H}} 6$ gene segments had the strongest binding interactions.

To extend these studies, phage-display library technology was used to investigate $\mathrm{pFv}$ binding within the repertoire from a healthy adult. As documented by sequence analysis and colony hybridization, panning of the IgM and IgG libraries with $\mathrm{pFv}$ selected predominantly for $\mathrm{V}_{\mathrm{H}} 3$ - and $\mathrm{V}_{\mathrm{H}} 6$-encoded $\mathrm{Fab}$, even though it is certain that the specific $V_{H}$ gene compositions within the two Fab libraries were very different. Antibodies encoded by $\mathrm{V}_{\mathrm{H}}$ 4-21 were obtained only from the $\mu$ library, but this may have been due to differential in vivo representation of $V_{H} 4-$ 21 rearrangements and/or primer usage in construction of the libraries. However, for both libraries, $\mathrm{pFv}$ binding repeatedly selected for antibodies with identical or clonally related $V_{H}$ genes that are paired with different $\mathrm{L}$ chains. These data and the very similar binding affinities of the IgM- $\kappa$ Fab and IgG- $\lambda$ Fab represent independent evidence that $\mathrm{L}$ chains are relatively passive and that $\mathrm{pFv}$ binding is likely mediated by contact areas in the portion of the $\mathrm{Fab}$ that comes from the $\mathrm{V}_{\mathrm{H}}$ gene segment. It is also clear that $\mathrm{pFv}$ interacts with a protein and not a carbohydrate site on Fab, because many of these studies used antibodies produced by bacteria.

In certain cases, panning with $\mathrm{pFv}$ selected for Fab with germline-encoded $\mathrm{V}_{\mathrm{H}}$ regions (Table III), but all selected $\mathrm{V}_{\mathrm{H}} 6$ Fab were found to be hypermutated, demonstrating that these mutations do not interfere with $\mathrm{pFv}$ binding. A likely explanation comes from previous reports that have detected only hypermutated $V_{H} 6$ regions in the adult repertoire $(40-43)$. Thus, even if nonmutated $V_{H}$ gene products are more commonly associated with optimal pFv binding, they could not be selected if they were not represented in the libraries.

Crystallographic studies have demonstrated that binding pockets for conventional antigens generally occur at the central confluence of the $\mathrm{H}$ and $\mathrm{L}$ chain CDR loops, and in most cases CDR3 loops, the subdomains of greatest diversity, are highly involved $(36,44,45)$. In contrast, the current variable region analyses did not detect conserved amino acid sequences in any of the CDR of $\mathrm{pFv}$ binders, and diverse $\mathrm{V}_{\mathrm{H}} \mathrm{CDR} 3$ were demonstrated to be permissive of $\mathrm{pFv}$ binding. However, the library studies did reveal preferential selection for $\mathrm{V}_{\mathrm{H}} \mathrm{CDR} 3$ of a small size. Although the CDR3 could still directly contribute to the pFv-binding site, another plausible explanation is that CDR3 of a particular size are more favorable for the expression of desired conformations of contact sites in another subdomain(s) of the Fab. Alternatively, significantly larger $V_{H}$ CDR3 loops may be selected against because they often protrude from the surface of the classic antigen-binding site (46) and may interfere with access of $\mathrm{pFv}$ to another surface of the Fab.

Conserved sequences in the $V_{H}$ framework regions (FRs) correlated best with pFv binding capacity. The FR1 and FR3 subdomains create a large solvent-exposed surface separate from the classic antigen-binding pocket, and this surface is highly superimposable on antibodies of the same $V_{H}$ family $(44,45,47)$. Significantly, antibodies encoded by $V_{H} 26 c / V 3-$ 23 , which were found to have among the strongest $\mathrm{pFv}$ binding interactions, contain one of the most highly conserved $\mathrm{V}_{\mathrm{H}}$ FR1/ FR3 surfaces within the human genome (reference 47; G. J. Silverman, manuscript in preparation). This gene also shares high homology with antibody genes from other species with prevalent Fab-mediated binding activity for $\mathrm{pFv}(4,47)$.

The current study was not designed to discriminate amino acids that correlate with $\mathrm{pFv}$ binding from those retained because they help to maintain the overall "immunoglobulin fold" (45), but comparison of $V_{H}$ sequences indicate that the recurrently selected $\mathrm{pFv}$ binders from the libraries all share cationic residues at the tip of the FR3 loop that are absent in $\mathrm{V}_{\mathrm{H}} 1$ chains which bind $\mathrm{pFv}$ weakly or not at all. The 3 sequential lysines at this site in the $V_{H}$ regions of the group $B$ antibodies have not been previously reported in germline or somatic $V_{H}$ variants, but the selection of this unusual variant further supports a role for cationic residues in $V_{H}$ FR3 loop in binding of this endogenous sialoprotein. The unexpected finding of $\mathrm{pFv}$ binding among bacterially expressed $\mathrm{V}_{\mathrm{H}} 4 \mathrm{Fab}$, but the uncommon binding among intact $\mathrm{V}_{\mathrm{H}} 4 \mathrm{IgM}$, also raises the question of whether $\mathrm{N}$-linked glycosylation at potential sites in $\mathrm{V}_{\mathrm{H}} 4$ antibodies (that are generally absent in other families) can adversely influence binding. $\mathrm{N}$-linked glycosylation of equivalent sites on a $\mathrm{T}$ cell receptor has been demonstrated to abolish binding of a $\mathrm{T}$ cell superantigen (48). Mutagenesis studies will be required to address these topics further.

The implications for the production of $\mathrm{pFv}$ in the body are little understood, and all of the immune properties of $\mathrm{pFv}$ described to date derive from in vitro studies. Though it has not yet been examined, we speculate that after $\mathrm{pFv}$ associates with immune complexes within the gut, it may accompany the immune complexes during transepithelial cell transport and influence antigen processing $(49,50)$. B lymphocytes that express surface Ig with rheumatoid factor (anti-IgG Fc) activity have been shown to be highly efficient at the capture of small amounts of antigen-associated immune complexes, which results in efficient presentation of a conventional antigen at 1,000fold lower concentrations than monocytes or macrophages (51). By analogy, nearly all B lymphocytes should be able to interact via their surface Ig with $\mathrm{pFv}$-associated immune complexes, which should greatly amplify the capacity to internalize and process conventional antigens in an immune complex. This proposed mechanism, in which $\mathrm{pFv}$ assists the immune response to ingested antigens, may contribute to the process in which oral immunization of humans results in B cell sensitization and not tolerance (52).

An influence on repertoire selection should also be considered. In the mouse, there is evidence that during lymphogenesis, certain $\mathrm{V}_{\mathrm{H}}$ gene segments are used based on their relative position in the Ig locus, with more $\mathrm{J}_{\mathrm{H}}$ proximal genes being preferentially rearranged (53). Although this may explain the preferential use of the human $\mathrm{V}_{\mathrm{H}} 6$ gene (54-58), which is most $\mathrm{J}_{\mathrm{H}}$ proximal $(33,59-61)$, it certainly does not explain the overexpression of other genes, such as $\mathrm{V}_{\mathrm{H}} 26 \mathrm{c} / \mathrm{V} 3-23,1.9 \mathrm{III} / \mathrm{V} 3-30$, and 4-21/V4-34 $(40,41,54,55,57,62-64)$, that are scattered throughout the $V_{H}$ locus (61). Auto-antibody-mediated interactions, which include anti-idiotypes, rheumatoid factors, antired cell membrane, anti-DNA, and other specificities, have all been discussed as surrogates for the foreign antigens that later direct $B$ cell repertoire selection $(23,25,65-67)$. However, the earliest $B$ lymphogenesis occurs in the liver, which suggests that if it is produced during in utero development, $\mathrm{pFv}$ could potentially bias clonal selection of the early $B$ cell repertoire. The evidence that $\mathrm{V}$ gene segments which are overexpressed in the early repertoire may have preferential binding interactions with $\mathrm{pFv}$ makes this hypothesis even more appealing. Preferential binding interactions with $B$ cell receptors with small $V_{H}$ CDR3, a pattern more common during early ontogeny $(38,39)$, are also consistent with this speculation. Taken together, the demonstrated high affinity of antibody interactions, potential 
for multivalent interactions, known localization to the liver, and the broad range of Fab that can bind all favor a role for $\mathrm{pFv}$ in receptor-mediated selection of the human B lymphocyte repertoire.

In summary, recent studies have demonstrated that there is a class of proteins for which there are naturally occurring B cell receptor-binding sites that are created predominantly by the contribution of the $V_{H}$ gene segment. The minimal structural requirements for the creation of these sites explain why they are highly prevalent among human lymphocyte populations. Within the current studies, we have investigated the molecular basis for Fab-mediated binding of pFv. This human liver protein has the broadest of known variable region mediated-Fab binding capacities and thus the highest frequency of binding interactions with the antibody repertoire of any protein characterized to date. Within the gut, the compartmentalized and regulated expression of $\mathrm{pFv}$ may greatly contribute to $\mathrm{B}$ cell/antibodymediated immune defenses. Recent reports suggest that SpA and the gp120 envelope proteins of certain HIV-1 strains also interact with similar $V_{H}$ sites $(6-9,22,68-70)$. Although yet to be proven, these infectious pathogens may have co-opted a physiologic Fab binding functional capacity, to interfere with opsonization of pathogens and normal B cell regulation within extravascular sites. Further studies will be required to investigate the physiologic expression of $\mathrm{pFv}$ and consider the role of $\mathrm{pFv}$ in the acquisition of immune competence.

\section{Acknowledgments}

We thank René Pirès for his expert technical assistance, Drs. Denise Shaw, Richard Insel, David Stollar, Katherine Siminovitch, and Ton Logtenberg for their generous gifts of IgM proteins, and Harry W. Schroeder, Jr. for valuable insights and the control $V_{H}$ plasmids.

This work was supported in part by National Institutes of Health (NIH) grants AI34001 and AR07567. Computational analyses were aided by NIH National Center for Research Resources GCRC grant M01 RR00833 to The Scripps Research Institute. G. J. Silverman is a recipient of a Biomedical Sciences Award from the Arthritis Foundation and is a Scholar of the Lupus Foundation of America, Inc.

\section{References}

1. Ruffet, E., R. Pires, J. Pillot, and J. P. Bouvet. 1994. Activation of the classical pathway of complement by non-immune complexes. Scand. J. Immunol. 40:359-362.

2. Patella, V., J. P. Bouvet, and G. Marone. 1993. Protein Fv produced during vital hepatitis is a novel activator of human basophils and mast cells. J. Immunol. 151:5685-5698.

3. Bouvet, J. P., R. Pires, S. Iscaki, and J. Pillot. 1993. Nonimmune macromolecular complexes of Ig in human gut lumen. Probable enhancement of antibody functions. J. Immunol. 151:2562-2571.

4. Bouvet, J. P., R. Pires, J. Charlemagne, J. Pillot, and S. Iscaki. 1991. Non-immune binding of human protein $\mathrm{Fv}$ to immunoglobulins from various mammalian and non-mammalian species. Scand. J. Immunol. 34:491-496.

5. Bouvet, J. P., R. Pires, C. Quan, S. Iscaki, and J. Pillot. 1991. Non-immune $\mathrm{V}_{\mathrm{H}}$-binding specificity of human protein Fv. Scand. J. Immunol. 33:381-386.

6. Sasso, E. H., G. J. Silverman, and M. Mannik. 1989. Human IgM molecules that bind staphylococcal protein A contain $\mathrm{V}_{\mathrm{H}}$ III H chains. J. Immunol. 142:27782783.

7. Sasso, E. H., G. J. Silverman, and M. Mannik. 1991. Human IgA and IgG $\mathrm{F}\left(\mathrm{ab}^{\prime}\right) 2$ that bind to staphylococcal protein $A$ belong to the $\mathrm{V}_{\mathrm{H}}$ III subgroup. $J$. Immunol. 147:1877-1883.

8. Silverman, G. J. 1992. Human antibody responses to bacterial antigens: studies of a model conventional antigen and a proposed model B cell superantigen. Int. Rev. Immunol. 9:57-78.

9. Sasano, M., D. R. Burton, and G. J. Silverman. 1993. Molecular selection of human antibodies with an unconventional bacterial B cell antigen. J. Immunol. 151:5822-5839.

10. Silverman, G. J., M. Sasano, and S. B. Wormsley. 1993. The variable- region specificity of bacterial Fab-binding proteins: the search for B cell superantigens. ImmunoMethods. 2:17-23.

11. Bouvet, J. P., R. Pires, F. Lunel-Fabiani, B. Crescenzo-Chaigne, P. Maillard, D. Valla, P. Opolon, and J. Pillot. 1990. Protein F. A novel F(ab)-binding factor, present in normal liver, and largely released in the digestive tract during hepatitis. J. Immunol. 145:1176-1180.

12. Towbin, H., T. Staehelin, and J. Gordon. 1979. Electrophoretic transfer of proteins from polyacrylamide gels to nitrocellulose sheets: procedure and some applications. Proc. Natl. Acad. Sci. USA. 76:4350-4354.

13. Silverman, G. J., R. E. Schrohenloher, M. A. Accavitti, W. J. Koopman, and D. A. Carson. 1990. Structural characterization of the second major crossreactive idiotype group of human rheumatoid factors. Association with the $\mathrm{V}_{\mathrm{H}} 4$ gene family. Arthritis Rheum. 33:1347-1360.

14. Silberstein, L. E., L. C. Jefferies, J. Goldman, D. Friedman, J. S. Moore, P. C. Nowell, D. Roelcke, W. Pruzanski, J. Roudier, and G. J. Silverman. 1991. Variable region gene analysis of pathologic human autoantibodies to the related $\mathrm{i}$ and I red blood cell antigens. Blood. 78:2372-2386.

15. Barbas, C. F., A. S. Kang, R. A. Lerner, S. J. Benkovic, and K. D. Janda. 1991. Assembly of combinatorial antibody libraries on phage surfaces: the gene III site linkage of recognition and replication functions by assembling combinatorial antibody Fab libraries along phage surfaces. Proc. Natl. Acad. Sci. USA. 88:43634366.

16. Barbas, C. F., III, and R. A. Lerner. 1991. Combinatorial immunoglobulin libraries on the surface of phage (phabs): rapid selection of antigen-specific fabs. Methods: Companion Methods Enzymol. 2:119-125.

17. Burton, D. R., C. F. Barbas, M. A. Persson, S. Koenig, R. M. Chanock, and R. A. Lerner. 1991. A large array of human monoclonal antibodies to type 1 human immunodeficiency virus from combinatorial libraries of asymptomatic seropositive individuals. Proc. Natl. Acad. Sci. USA. 88:10134-10137.

18. Granzow, R., and R. Reed. 1992. Interactions in the fourth dimension. Bio/Technology. 10:390-395.

19. Malmqvist, M. 1993. Surface plasmon resonance for the detection and measurement of antibody-antigen affinity and kinetics. Curr. Opin. Immunol. 5:282-286.

20. Parmley, S. F., and G. P. Smith. 1988. Antibody-selectable filamentous fd phage vectors: affinity purification. Gene. 73:305-318.

21. Sambrook, J., E. F. Fritsch, and T. Maniatis. 1989. Molecular Cloning: A Laboratory Manual. Cold Spring Harbor Laboratory. Cold Spring Harbor, NY.

22. Hillson, J. L., N. S. Karr, I. R. Oppliger, M. Mannik, and E. H. Sasso. 1993. The structural basis of germline-encoded $V_{\mathrm{H}} 3$ immunoglobulin binding to staphylococcal protein A. J. Exp. Med. 178:331-336.

23. Dersimonian, H., R. S. Schwartz, K. J. Barrett, and B. D. Stollar. 1987. Relationship of human variable region heavy chain germ-line genes to genes encoding anti-DNA antibodies. J. Immunol. 139:486-501.

24. Chen, P. P., M. F. Liu, S. Sinha, and D. A. Carson. 1988. A $16 / 6$ idiotypepositive anti-DNA antibody is encoded by a conserved $V_{H}$ gene with no somatic mutation. Arthritis Rheum. 31:1429-1431.

25. Cairns, E., P. C. Kwong, V. Misener, P. Ip, D. A. Bell, and K. A. Siminovitch. 1989. Analysis of variable region genes encoding a human antiDNA antibody of normal origin: implications for the molecular basis of human autoimmune responses. J. Immunol. 143:685-691.

26. Schroeder, H. W., Jr., F. S. Stuber, P. M. Kirkham, B. M. Gray, J.-J. Tzeng, and D. R. Shaw. 1992. Sequence analysis of two human antibodies with specificity for type 3 pneumococcal polysaccharide (PPS-3). FASEB (Fed. Am. Soc. Exp. Biol.) J. 6:A1648.

27. Logtenberg, T., F. M. Young, J. H. Van Es, F. Gmelig-Meying, and F. W. Alt. 1989. Autoantibodies encoded by the most Jh-proximal human immunoglobulin heavy chain variable region gene. J. Exp. Med. 170:1347-1355.

28. Varade, W. S., and R. A. Insel. 1993. Isolation of germinal centerlike events from human spleen RNA. Somatic hypermutation of a clonally related $\mathrm{V}_{\mathrm{H}} 6 \mathrm{DJH}$ rearrangement expressed with IgM, IgG and IgA. J. Clin. Invest. 91:1838-1842.

29. Tomlinson, I. M., G. Walter, J. D. Marks, M. B. Llewelyn, and G. Winter 1992. The repertoire of human germline $V_{H}$ sequences reveals about fifty groups of $\mathrm{V}_{\mathrm{H}}$ segments with different hypervariable loops. J. Mol. Biol. 227:776-798.

30. Matthyssens, G., and T. H. Rabbitts. 1980. Structure and multiplicity of genes for the human immunoglobulin heavy chain variable region. Proc. Natl. Acad. Sci. USA. 77:6561-6565.

31. Sanz, I., P. Kelly, C. Williams, S. Scholl, P. Tucker, and J. D. Capra. 1989. The smaller human $V_{H}$ gene families display remarkably little polymorphism. EMBO (Eur. Mol. Biol. Org.) J. 8:3741-3748.

32. Demaison, C., P. Chastagner, J. Theze, and M. Zouali. 1994. Somatic diversification in the heavy chain variable region genes expressed by human autoantibodies bearing a lupus-associated nephritogenic anti-DNA idiotype. Proc. Natl. Acad. Sci. USA. 91:514-518.

33. Berman, J., S. J. Mellis, R. Pollock, C. L. Smith, H. Suh, B. Heinke, C. Kowal, U. Surti, L. Chess, C. R. Cantor, and F. W. Alt. 1988. Content and organization of the human immunoglobulin $I g \mathrm{~V}_{\mathrm{H}}$ locus: definition of three new families and linkage to the Ig CH locus. EMBO (Eur. Mol. Biol. Org.) J. 7:727738.

34. Zelenetz, A. D., T. T. Chen, and R. Levy. 1992. Clonal expansion in 
follicular lymphoma occurs subsequent to antigenic selection. J. Exp. Med. 176:1137-1148

35. Olee, T., P. M. Yang, K. A. Siminovitch, N. J. Olsen, J. Hillson, J. Wu, F. Kozin, D. A. Carson, and P. P. Chen. 1991. Molecular basis of an autoantibodyassociated restriction fragment length polymorphism that confers susceptibility to autoimmune diseases. J. Clin. Invest. 88:193-203.

36. Kabat, E. A., T. T. Wu, H. M. Perry, K. S. Gottesman, and C. Foeller. 1991 Sequences of proteins of immunological interest. 5th edition. U.S. Department of Health and Human Services, Public Health Service, National Institutes of Health Bethesda, MD.

37. Chothia, C., and A. M. Lesk 1987. Canonical structures for the hypervariable regions of immunoglobulins. J. Mol. Biol. 196:901-917.

38. Yamada, M., R. Wasserman, B. A. Reichard, S. Shane, A. J. Caton, and G. Rovera. 1991. Preferential utilization of specific immunoglobulin heavy chain diversity and joining segments in adult human peripheral blood B lymphocytes. J. Exp. Med. 173:395-407.

39. Sanz, I. 1991. Multiple mechanisms participate in the generation of diversity of human H chain CDR3 regions. J. Immunol. 147:1720-1729.

40. Huang, C., and B. D. Stollar. 1993. A majority of Ig H chain cDNA of normal human adult blood lymphocytes resembles cDNA for fetal Ig and natura autoantibodies. J. Immunol. 151:5290-5300.

41. Huang, C., A. K. Stewart, R. S. Schwartz, and B. D. Stollar. 1992. Immunoglobulin heavy chain gene expression in peripheral blood B lymphocytes. $J$. Clin. Invest. 89:1331-1343.

42. Van Es, J. H., F. H. Meyling, and T. Logtenberg. 1992. High frequency of somatically mutated IgM molecules in the human adult blood B cell repertoire. Eur. J. Immunol. 22:2761-2764.

43. Varade, W. S., E. Marin, A. M. Kittelberger, and R. A. Insel. 1993. Use of the most $\mathrm{J}_{\mathrm{H}}$-proximal human $\operatorname{Ig} \mathrm{H}$ chain $\mathrm{V}$ region gene, $\mathrm{V}_{\mathrm{H}} 6$, in the expressed immune repertoire. J. Immunol. 150:4985-4995.

44. Padlan, E. A. 1994. Anatomy of the antibody molecule. Mol. Immunol. 31:169-217.

45. Poljak, R. J., L. M. Amzel, B. L. Chen, R. P. Phizackerley, and F. Saul 1974. The three-dimensional structure of the fab' fragment of a human myeloma immunoglobulin at 2.0-angstrom resolution. Proc. Natl. Acad. Sci. USA. 71:34403444.

46. Wu, T. T., G. Johnson, and E. A. Kabat. 1993. Length distribution of CDRH3 in antibodies. Proteins. 16:1-7.

47. Schroeder, H. W. J., J. L. Hillson, and R. M. Perlmutter. 1990. Structure and evolution of mammalian $\mathrm{V}_{\mathrm{H}}$ families. Int. Immunol. 2:41-50.

48. Pullen, A. M., J. Bill, R. T. Kubo, P. Marrack, and J. W. Kappler. 1991 Analysis of the interaction site for the self superantigen Mls-1a on T cell recepto V beta. J. Exp. Med. 173:1183-1192.

49. Wolf, J. L., and W. A. Bye. 1984. The membranous epithelial (M) cell and the mucosal immune system. Annu. Rev. Med. 35:95-112.

50. Owen, R. L., A. J. Piazza, and T. H. Ermak. 1991. Ultrastructural and cytoarchitectural features of lymphoreticular organs in the colon and rectum of adult BALB/c mice. Am. J. Anat. 190:10-18.

51. Roosnek, E., and A. Lanzavecchia. 1991. Efficient and selective presentation of antigen-antibody complexes by rheumatoid factor B cells. J. Exp. Med. 173:487-489.

52. Husby, S., J. Mestecky, Z. Moldoveanu, S. Holland, and C. O. Elson 1994. Oral tolerance in humans. $T$ cell but not B cell tolerance after antigen feeding. J. Immunol. 152:4663-4670.

53. Yancopoulos, G. D., S. V. Desiderio, M. Paskind, J. F. Kearney, D.
Baltimore, and F. W. Alt. 1984. Preferential utilization of the most $\mathrm{J}_{\mathrm{H}}$-proximal $\mathrm{V}_{\mathrm{H}}$ gene segments in pre-B-cell lines. Nature (Lond.). 311:727-733.

54. Schroeder, H. W. J., Jr., J. L. Hillson, and R. M. Perlmutter. 1987. Early restriction of the human antibody repertoire. Science (Wash. DC). 238:791-793.

55. Schroeder, H. W. J., Jr., and J. K. Wang. 1990. Preferential utilization of conserved immunoglobulin heavy chain variable gene segments during human fetal life. Proc. Natl. Acad. Sci. USA. 87:6146-6150.

56. Berman, J. E., K. G. Nickerson, R. R. Pollock, J. E. Barth, R. K. Schuurman, D. M. Knowles, L. Chess, and F. W. Alt. 1991. $V_{H}$ gene usage in humans biased usage of the $\mathrm{V}_{\mathrm{H}} 6$ gene in immature B lymphoid cells. Eur. J. Immunol. 21:1311-1314.

57. Cuisinier, A. M., L. Gauthier, L. Boubli, M. Fougereau, and C. Tonnelle. 1993. Mechanisms that generate human immunoglobulin diversity operate from the 8th week of gestation in fetal liver. Eur. J. Immunol. 23:110-118.

58. Van Es, J. H., F. M. Raaphorst, M. J. van Tol, F. H. Meyling, and T. Logtenberg. 1993. Expression pattern of the most $J_{H}$-proximal human $V_{H}$ gene segment $\left(\mathrm{V}_{\mathrm{H}} 6\right)$ in the $\mathrm{B}$ cell and antibody repertoire suggests a role of VH6encoded IgM antibodies in early ontogeny. J. Immunol. 150:161-168.

59. Schroeder, H. W. J., M. A. Walter, M. H. Ho f ker, A. Ebens, K. Willems van Dijk, L. C. Liao, D. W. Cox, E. C. Milner, and R. M. Perlmutter. 1988. Physical linkage of a human immunoglobulin heavy chain variable region gene segment to diversity and joining region elements. Proc. Natl. Acad. Sci. USA. 85:8196-8200.

60. Buluwela, L., and T. H. Rabbitts. 1988. A $\mathrm{V}_{\mathrm{H}}$ gene is located within 95 $\mathrm{Kb}$ of the human immunoglobulin heavy chain constant region genes. Eur. J. Immunol. 18:1843-1845.

61. Matsuda, F., E. K. Shin, H. Nagaoka, R. Matsumura, M. Haino, Y. Fukita, S. Taka-ishi, T. Imai, J. H. Riley, R. Anand, E. Soeda, and T. Honjo. 1993 Structure and physical map of 64 variable segments in the 3' 0.8 megabase region of the human immunoglobulin heavy-chain locus. Nature Genet. 3:88-94.

62. Stewart, A. K., C. Huang, B. D. Stollar, and R. S. Schwartz. 1993. Highfrequency representation of a single $V_{H}$ gene in the expressed human $B$ cell repertoire. J. Exp. Med. 177:409-418.

63. Stevenson, F. K., G. J. Smith, J. North, T. J. Hamblin, and M. J. Glennie. 1989. Identification of normal B-cell counterparts of neoplastic cells which secrete cold agglutinins of anti-I and anti-i specificity. Br. J. Hematol. 72:9-15.

64. Schutte, M. E., J. H. Van Es, L. E. Silberstein, and T. Logtenberg. 1993 $\mathrm{V}_{\mathrm{H}}$ 4.21-encoded natural autoantibodies with anti-i specificity mirror those associated with cold hemagglutinin disease. J. Immunol. 151:6569-6576.

65. Kearney, J. F., M. Vakil, and N. Solvason. 1989. The role of idiotypic interactions and B-cell subsets in development of the B-cell repertoire. Cold. Spring. Harbor Symp. Quant. Biol. 54:203-207.

66. Holmberg, D., A. A. Freitas, D. Portnoi, F. Jacquemart, S. Avrameas, and A. Coutinho. 1986. Antibody repertoires of normal BALB/c mice: B lymphocyte populations defined by state of activation. Immunol. Rev. 93:147-169.

67. Schwartz, R. S., and B. D. Stollar. 1994. Heavy-chain directed B-cell maturation: continuous clonal selection beginning at the pre-B cell stage. Immunol. Today. 15:27-32.

68. Silverman, G. J., M. Sasano, and S. B. Wormsley. 1993. Age-associated changes in binding of human $B$ lymphocytes to a $\mathrm{V}_{\mathrm{H}}$ 3-restricted unconventional bacterial antigen. J. Immunol. 151:5840-5855.

69. Silverman, G. J. 1994. Unconventional antigen-antibody binding interactions and B cell superantigens. Immunologist. 2:51-57.

70. Berberian, L., L. Goodglick, T. J. Kipps, and J. Braun. 1993. Immunoglobulin $\mathrm{V}_{\mathrm{H}} 3$ gene products: natural ligands for HIV gp120. Science (Wash. DC) 261:1588-1591. 